\title{
Upaya Meningkatkan Aktifits dan Hasil Belajar Penjaskes Peserta Didik kelas V.B Semester Dua Tahun Pelajaran 2017/2018 Melalui Penerapan Model Jigsaw di SD Negeri 19 Cakranegara
}

\author{
Maria Florida \\ Guru Penjaskes SD Negeri 19 Cakranegara
}

Penelitian ini bertujuan untuk mengetahui efektifitas penerapan pendekatan cooperative learning (CL) tipe Jigsaw dalam upaya meningkatkan aktifitas dan hasil belajar Penjaskes Peserta didik kelas V.B SD Negeri 19 Cakranegara. Manfaat penelitian ini adalah sebagai bahan kajian dan bahan temuan dalam pelaksanaan proses pembelajaran di kelas senyatanya. Bagi guru untuk meningkatkan kompetensi dalam proses pembelajaran dan bagi peserta didik untuk meningktakan aktifitas dan hasil belajar peserta didik. Penelitian ini dilaksanakan dua siklus, masing-masing siklus kegiatannya adalah; perencanaan, pelaksanaan, observasi dan refleksi. Hasil akhir tindakan pada siklus II menunjukkan bahwa hasil observasi guru memperoleh skor rata-rata $(4,30)$ dan hasil observasi peserta didik mencapai skor rata-rata $(4,35)$. Sedangkan hasil belajar peserta didik adalah mencapai nilai rata-rata $(92,83)$, artinya indikator keberhasilan $(\geq 75,00)$ telah terlampaui. Karena indikator keberhasilan telah terbukti penelitian dinyatakan berhasil dan dihentikan pada siklus II.

Kata Kunci : Aktifitas dan hasil Belajar - Penerapan Model Jigsaw

\section{PENDAHULUAN}

Proses pembelajaran bidang studi/mata pelajaran Pendidikan Jasmani Dan Kesehatan (Penjaskes), memiliki karakter yang berbeda dengan mata pelajaran pada umumnya. Proses pembelajaran Penjaskes mengutamakan pada skiil (ketrampilan) yang dipraktikkan secara langsung diluar kelas (lapangan/halaman sekolah), sehingga memerlukan tenaga fisik untuk melakukannya. Materi yang bersifat teoritis biasanya dilakukan di dalam kelas dengan menggunakan model pembelajaran yang bervariatif sesuai dengan tema yang diajarkan. Ada juga guru penjaaskes menyampaikan materi yang bersifat teoritis langsung disampaikan dilapangan. Setelah teori peserta didik diminta untuk memperagakan baik secara individual maupun secara klasikal. Misalnya guru menjelaskan tata cara permainan bola volly, selesai menjelaskan langsung memperaagakan, selanjutnya peserta didik secara berkelompok/perorangan untuk melakukan gerakan sebagaimana yang dicontohkan oleh gurunya.

Di SD Negeri 19 Cakranegara, khususnya peserta didik kelas V.B pada saat proses pembelajaran Penjaaskes, menggunakan model teori yang dilaksanakan di dalam kelas dan model praktiknya nyata di luar kelas/di lapangan dengan menggunakan seragam/pakaian olahraga SD Negeri 19 Cakranegara. Peserta didik secara umum telah mengikuti aturan main yang diberikan oleh guru. Akan tetapi masih saja ada peserta didik yang kurang disiplin, tidak serius mengikuti proses pembelajaran terutama pada waktu praktik di lapangan, ada yang membeli jajan/es dan sejenisnya pada saat proses pembelajaran berlangsung. ada juga yang hanya duduk melamun/berdiam diri tidak mengikuti secara utuh selama proses pembelajaran di luar kelas/lapangan.

Rendahnya aktifitas dan hasil belajar Penjaskes peserta didik kelas V.B SD Negeri 19 Cakranegara disebabkan karena : 1) guru mengajar hanya ceramah dan pemberian tugas yang jarang dikontrol (diawasi), 2) peserta didik kurang aktif dalam belajar karena hanya guru saja yang aktif berbicara dari awal sampai akhir pelajaran, 3) peserta didik banyak yang tidak mau mengerjakan tugas/soal yang diberikan oleh guru karena kurang memahami materi pelajaran, 4) standar krikteria ketuntasan minimal (KKM) terlalu tinggi untuk ukuran mata pelajaran 
Penjaskes, dan yang ke 5) hubungan individu antara guru dengan peserta didik kurang terjalin sehingga peserta didik terkesan takut dengan guru yang mengakibatkan aktifitas dan hasil belajar rendah.

Banyak solusi yang bisa dilakukan oleh peneliti diantaranya yaitu dengan menerapkan pendekatan Cooperative Learning (CL) tipe Jigsaw. Ada beberapa keunggulan tipe jigsaw dalam proses pembelajaran antara lain: 1) melatih berfikir mandiri yaitu suatu sikap dan perilaku yang tidak mudah tergantung pada orang lain dalam menyelesaikan tugas-tugas, 2) demokratis yaitu cara berfikir, bersikap, dan bertindak yang menilai sama hak dan kewajiban dirinya dan orang lain, 3) kerja keras yaitu perilaku yang menunjukkan upaya sungguh-sungguh dalam mengatasi berbagai hambatan belajar dan tugas, serta menyelesaikan tugas dengan sebaik-baiknya, 4) kreatif yaitu berfikir dan melakukan sesuatu untuk menghasilkan cara atau hasil baru dari sesuatu yang telah dimiliki, 5) komunikatif yaitu tindakan yang memperlihatkan rasa senang berbicara, bergaul dan bekerja sama dengan orang lain.

Untuk membuktikan beberapa keunggulan strategi jigsaw maka perlu diadakan Penelitian Tindakan Kelas (PTK) dengan judul " Upaya Meningkatkan Aktifits dan Hasil Belajar Penjaskes Peserta Didik kelas V.B Semester Dua Tahun Pelajaran 2017/2018 Melalui Penerapan Model Jigsaw di SD Negeri 19 Cakranegara".

\section{Rumusan Masalah}

"Apakah penerapan model jigsaw dapat meningkatkan aktifitas dan hasil belajar Penjaskes peserta didik kelas V.B SD Negeri 19 Cakranegara semester dua tahun pelajaran 2017/2018?

\section{Tujuan Penelitian}

"Untuk mengetahui efektifitas penerapan pendekatan cooperative learning (CL) tipe jigsaw dalam upaya meningkatkan aktifitas dan hasil belajar Penjaskes peserta didik kelas V.B SD Negeri 19 Cakranegara Semester dua tahun pelajaran 2017/2018".

\section{Manfaat Penelitian}

a. Bermanfaat bagi guru selaku peneliti dalam rangka melaksanakan proses pembelajaran yang kontekstual melalui penerapan pendekatan cooperative learning (CL) tipe jigsaw di kelas senyatanya serta dalam upaya perwujudan pembelajaran yang aktif, inovatif, kreatif, efektif, dan menyenangkan (PAIKEM) sehingga aktifitas dan hasil belajar peserta didik dapat ditingkatkan.

b. Bermanfaat bagi peserta didik dalam upaya meningkatkan prestasi belajar peserta didik.

\section{KAJIAN PUSTAKA Aktifitas Belajar}

Aktivitas belajar adalah aktivitas yang bersifat fisik maupun mental. Dalam proses belajar kedua aktivitas itu harus saling berkaitan. Lebih lanjut lagi piaget menerangkan dalam buku Sardiman bahwa jika seorang anak berfikir tanpa berbuat sesuatu, berarti anak itu tidak berfikir (Sardiman, 2011:100, Anonim: 2018).

Nanang Hanafiah dan Cucu Suhana (2010:24, Anonim: 2018) menjelaskan bahwa aktivitas belajar dapat memberikan nilai tambah (added value) bagi peserta didik, berupa hal-hal berikut ini:

1. Peserta didik memiliki kesadaran (awareness) untuk belajar sebagai wujud adanya aktifitas internal untuk belajar sejati.

2. Peserta didik mencari pengalaman dan langsung mengalami sendiri, yang dapat memberikan dampak terhadap pembentukan pribadi yang integral.

3. Peserta didik belajar dengan menurut minat dan kemampuannya.

4. Menumbuh kembangkan sikap disiplin dan suasana belajar yang demokratis di kalangan peserta didik.

5. Pembelajaran dilaksanakan secara konkret sehingga dapat menumbuh kembangkan pemahaman dan berfikir kritis serta menghindarkan terjadinya verbalisme.

6. Menumbuh kembangkan sikap kooperatif dikalangan peserta didik sehingga sekolah menjadi hidup, sejalan dan serasi 
dengan kehidupan di masyarakat di sekitarnya.

Dalam penelitian ini yang dimaksud dengan aktifitas belajar adalah kegiatan peserta didik mengingat, memecahkan masalah, menganalisis faktor-faktor, melihat hubungan-hubungan, dan membuat keputusan terhadap masalah yang diberikan oleh guru kelas V.B di SD Negeri 19 Cakranegara.

\section{Hasil Belajar}

Masalah belajar adalah masalah bagi setiap manusia, dengan belajar manusia memperoleh keterampilan, kemampuan sehingga terbentuklah sikap dan bertambahlah ilmu pengetahuan. Jadi hasil belajar itu adalah suatu hasil nyata yang dicapai oleh peserta didik dalam usaha menguasai kecakapan jasmani dan rohani di sekolah yang diwujudkan dalam bentuk raport pada setiap semester.

Untuk mengetahui perkembangan sampai di mana hasil yang telah dicapai oleh seseorang dalam belajar, maka harus dilakukan evaluasi. Untuk menentukan kemajuan yang dicapai maka harus ada kriteria (patokan) yang mengacu pada tujuan yang telah ditentukan sehingga dapat diketahui seberapa besar pengaruh strategi belajar mengajar terhadap keberhasilan belajar peserta didik. Hasil belajar peserta didik menurut W. Winkel (dalam buku Psikologi Pengajaran 1989:82, Anonim: 2018) adalah keberhasilan yang dicapai oleh peserta didik, yakni prestasi belajar peserta didik di sekolah yang mewujudkan dalam bentuk angka.

2. Indikator Hasil Belajar Peserta didik

Yang menjadi indikator utama hasil belajar peserta didik adalah sebagai berikut:

a. Ketercapaian Daya Serap terhadap bahan pembelajaran yang diajarkan, baik secara individual maupun kelompok. Pengukuran ketercapaian daya serap ini biasanya dilakukan dengan penetapan Kriteria Ketuntasan Belajar Minimal (KKM)

b. Perilaku yang digariskan dalam tujuan pembelajaran telah dicapai oleh peserta didik, baik secara individual maupun kelompok.
Namun demikian, menurut Syaiful Bahri Djamarah dan Aswan Zain (dalam buku Strategi Belajar Mengajar 2002:120, Anonim: 2018) indikator yang banyak dipakai sebagai tolak ukur keberhasilan adalah daya serap.

Dalam penelitian ini yang dimaksud dengan hasil belajar adalah laporan individu dan tes dalam bentuk tertulis yang materi soalnya hanya selintas apa yang disajikan oleh guru selama prose pembelajaran di kelas. Dalam hal ini adalah materi pembelajaran Penjaskes kelas V.B.

\section{Pendekatan CooperativeLearning (CL)}

Al Hakim dan Rianto (2002) dalam bukunya strategi pembelajaran berdasarkan Deep Dialugue/Critical Thinking (DD/CT) menjelaskan bahwa pendekatan Cooperative Learning (CL) sebagai model pembelajaran dalam kelompok-kelompok kecil dimana peserta didik belajar dan bekerjasama untuk mencapai tujuan seoptimal mungkin. Esensinya terletak pada tanggung jawab individu sekaligus kelompok, sehingga dalam setiap peserta didik tumbuh berkembang sikap perilaku saling ketergantungan (interpedensi) secara positif. Dengan demikian menjadikan belajar melalui kerjasama dalam kelompok akan berjalan seoptimal mungkin. Kondisi ini dapat mendorong peserta didik untuk belajar, bekerja, dan bertanggung jawab secara sungguh-sungguh sampai tujuan dapat diwujudkan.

Pembelajaran cooperative learning akan memberikan manfaat bagi peserta didik dalam: a) meningkatkan kemampuan untuk bekerjasama dan bersosialisasi, b) melatih kepekaan diri, empati melalui perbedaan sikap-perilaku selama bekerjasama, c) upaya mengurangi rasa kecemasan dan menumbuhkan rasa percaya diri, d) meningkatkan aktifitas belajar (partisipasi dan minat), harga diri dan sikap-perilaku yang positif, serta e) meningkatkan prestasi belajarnya.

\section{Kerangka Konseptual}

Hubungan antara variabel harapan yaitu meningkatnya aktifitas dan hasil belajar peserta didik dengan variabel tindakan yaitu 
penerapan pendekatan Cooperative Learning CL tipe jigsaw.

\section{Hipotesis Tindakan}

"Penerapan pendekatan Cooperative Learning (CL) tipe jigsaw dapat meningkatkan aktifitas dan hasil belajar peserta didik kelas V.B SD Negeri 19 Cakranegara semester dua Tahun pelajaran 2017/2018".

\section{PROSEDUR PENELITIAN}

Penelitian tindakan kelas (PTK) ini akan dilaksanakan di kelas V.B SD Negeri 19 Cakranegara semester dua tahun pelajaran 2017/2018, dengan jumlah peserta didik sebanyak 30 orang.

\section{Faktor yang Diteliti}

1. Faktor Guru: yaitu dengan mengamati cara guru membuat Rencana Pelaksanaan Pembelajaran (RPP) dan pelaksanaannya dalam pembelajaran di kelas senyatanya dengan menerapkan pendekatan Cooperatif Learning (CL) tipe Jigsaw dalam upaya meningkatkan aktifitas dan hasil belajar Penjaskes peserta didik Kelas V.B SD Negeri 19 Cakranegara.

2. Faktor Peserta didik: yaitu peningkatan aktifitas belajar peserta didik yang terlihat pada saat melaksanakan diskusi kelompok, dan pada saat tes tertulis di akhir pembelajaran bagi peserta didik kelas V.B Semester dua Tahun pelajaran 2017/2018 di SD Negeri 19 Cakranegara.

\section{Rencana Tindakan}

Tindakan nyata yang dilakukan oleh guru selaku peneliti adalah dengan menggunakan siklus. Gambaran siklus dalam penelitian ini adalah sebagai berikut:

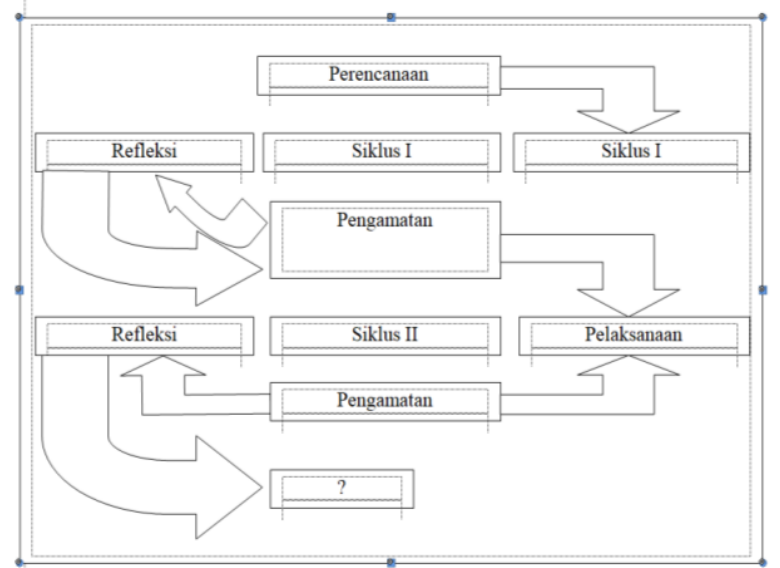

Setiap siklus selama penelitian ini berisi 4 (empat) tahapan yaitu: 1) Perencanaan (Planning), 2) Pelaksanaan (Action), 3) Observasi (Observation), dan 4) Refleksi (Reflection).

\section{Siklus Tindakan}

\section{SIKLUS I}

1) Tahap Perencanaan (Planning)

1. Menyusun Rencana Pelaksanaan Pembelajaran (RPP) dengan skenario sesuai dengan aturan main model pembelajaran Cooperatif learning (CL) tipe Jigsaw.

2. Menyiapkan sumber, bahan, dan semua alat yang digunakan dalam penelitian.

3. Menyusun/membuat lembar observasi guru dan lembar observasi peserta didik.

4. Menyusun alat evaluasi.

2) Tahap Pelaksanaan (Action)

\section{Pertemuan I}

1. Guru membagi peserta didik menjadi 10 (sepuluh) kelompok kecil, masing-masing kelompok beranggotakan 3 orang peserta didik.

2. Melakukan proses pembelajaran dengan pendekatan CL tipe Jigsaw sebagai berikut:

a. Kelompok Kooperatif

- Peserta didik yang berjumlah 30 orang dibagi menjadi 10 (sepuluh) kelompok, masing-masing kelompok beranggotakan 3 (tiga) orang.

- Masing-masing kelompok menunjuk 1 (satu) orang sebagai ketua kelompok

- Ketua kelompok maju kedepan untuk mendapatkan petunjuk dari guru kelas (guru Penjaskes) yang isinya:

1. Masing-masing kelompok mendapatkan 3 (tiga) kartu berisikan soal yang berbeda

2. Ketua kelompok membagikan kartu soal secara acak

3. Tiap-tiap peserta didik mengerjakan soal yang berbeda secara mandiri/individual sesuai waktu yang telah ditentukan

b. Kelompok Ahli

- Peserta didik memilih kartu soal yang sama berkumpul menjadi 3 (tiga) kelompok yang anggotanya masingmasing 10 (sepuluh) orang 
- Masing-masing kelompok ahli mendiskusikan hasil kerja individual untuk dicari jawaban final hasil dari diskusi kelompok

- Masing-masing kelompok merencanakan cara menyampaikan dengan kelompok semula yang namanya berganti menjadi kelompok tiga serangkai.

c. Kelompok Tiga Serangkai

- Masing-masing anggota kelompok menyampaikan hasil kerja kelompok ahli sesuai dengan kesepakatan yang telah diputuskan bersama dalam kelompok ahli

- Masing-masing anggota kelompok menulis hasil informasi yang disampaikan oleh anggota kelompoknya.

- Hasil akhir dikumpulkan untuk di nilai oleh guru kelas/guru Penjaskes.

\section{Pertemuan II}

d. Praktik lapangan : Masing-masing kelompok mendemonstrasikan cara berlari/atletik dihadapan semua peserta didik secara bergiliran.

e. Tes tertulis

3) Tahap Observasi (Observation)

Pada tahapan observasi ini diadakan pengamatan oleh observer untuk mengamati :

1. Observasi guru : Dilakukan oleh pengawas pembimbing dalam melaksanakan Penelitian Tindakan Kelas (PTK).

2. Observasi Peserta didik : Dilakukan oleh guru kelas sebagai peneliti dalam Penelitian Tindakan Kelas (PTK) pada kegiatan diskusi kelompok dan presentasi kelompok.

4). Tahap Refleksi (Reflection)

1. Renungan hasil perolehan data

2. Pengolahan dan analisa data hasil penelitian

3. Mencocokkan hasil analisa data dengan indikator keberhasilan

4. Rencana perbaikan dan tindak lanjut

SIKLUS II

Pada siklus ini semua kegiatan dan tahapan selama penelitian adalah sama, sifatnya mengulang dan memperbaiki terhadap tindakan yang masih memerlukan penyempurnaan dan pembenaran sebagaimana mestinya.

\section{Data dan Cara Pengambilannya. Sumber Data}

Yang menjadi sumber data dalam penelitian tindakan kelas (PTK) ini adalah semua peserta didik kelas V.B SD Negeri 19 Cakranegara semester dua tahun pelajaran 2017/2018 dan guru kelas/mata pelajaran Penjaskes.

\section{Jenis Data}

- Jenis data yang berasal dari guru selaku peneliti

1). Data tentang Rencana Pelaksanaan Pembelajaran (RPP)

2). Data Pelaksanaan Pembelajaran

- Jenis data yang berasal dari peserta didik : 1). Data kemajuan aktifitas belajar

2). Data hasil laporan individu hasil diskusi kelompok

3). Data hasil belajar peserta didik/tes tertulis

\section{Cara Pengambilan data}

- Data kegiatan pembelajaran diambil dari RPP yang dibuat oleh guru dan lembar observasi pelaksanaan model pembelajaran Cooperative Learning (CL) tipe Jigsaw

- Data kemajuan aktifitas belajar; diambil dari lembar observasi selama kerja kelompok dan presentasi kelompok.

- Data kemajuan hasil belajar; diambil dari laporan hasil kerja kelompok secara individual dan nilai hasil tes tertulis yang dilaksanakan pada akhir proses pembelajaran

\section{Indikator Keberhasilan dan Teknik analisa}

\section{data}

\section{Teknik analisa data}

Untuk menganalisis data akan dilakukan melalui analisis deskriptif kuantitatif melalui pendataan, analisis dan pembahasan terhadap data yang diperoleh dengan mencocokkan tingkat keoptimalan terhadap capaian indikator keberhasilan yang ada.

\section{Indikator Keberhasilan}

1. guru telah dinyatakan berhasil melaksanakan proses pembelajaran dengan pendekatan Cooperative Learning (CL) tipe Jigsaw, bila telah mencapai skor ratarata $\geq 4,00$ 
2. aktifitas belajar Penjaskes peserta didik kelas V.B dinyatakan telah meningkat jika $\geq 85 \%$ dari jumlah peserta didik telah memperoleh skor rata-rata $\geq 4,0$ (kategori baik) dan hasil belajar dinyatakan telah meningkat jika $\geq 85 \%$ dari jumlah peserta didik memperoleh nilai rata-rata $\geq 75,00$ (KKM Peserta didik).

\section{LAPORAN HASIL DAN PEMBAHASAN DESKRIPSI SIKLUS I}

Tahap Perencanaan

Pada tahapan ini yang telah dilakukan oleh guru selaku peneliti adalah; 1) menyusun RPP dengan skenario pembelajaran CL Tipe Jigsaw, 2) telah berhasil menyiapkan alat, sumber, bahan yang diperlukan dalam penelitian, 3) berhasil menyusun instrument observasi guru dan instrument observasi peserta didik, dan 4) menyusun alat evaluasi.

\section{Tahap Pelaaksanaan \\ Pertemuan I}

a. Kelompok Kooperatif

- Peserta didik yang berjumlah 30 orang dibagi menjadi 10 (sepuluh) kelompok, masing-masing kelompok beranggotakan 3 orang

- Masing-masing anggota kelompok diberikan kartu soal yang berlainan untuk dikerjakan secara individual dalam waktu yang ditentukan.

b. Kelompok Ahli

- Peserta didik yang memiliki kartu soal yang sama dikumpulkan sehingga menjadi 3 (tiga) kelompok besar, dan masing-masing kelompok beranggotakan 10 orang (kelompok ahli)

- Ketua kelompok ahli mendiskusikan soal yang sama untuk dipecahkan secara bersama-sama

- Hasil kesepakatan semua kelompok di tulis oleh semua anggota di lembar kerja yang telah disiapkan

- Masing-masing kelompok merencanakan cara menyampaikan dengan anggota kelompok semula yang selanjutnya disebut dengan kelompok tiga serangkai c. Kelompok Tiga Serangkai

- Masing-masing anggota kelompok secara bergiliran menyampaikan hasil kerja kelompok ahli

- Masing-masing anggota kelompok mencatat hasil dari kerja kelompok ahli.

\section{Pertemuan II}

d. Masing-masing kelompok maju kedepan untuk mempresentasikan hasil kerja kelompok dihadapan semua peserta didik.

e. Tes tertulis.

\section{Tahap Observasi}

Observasi guru pertemuan I memperoleh skor rata-rata sebesar $(3,00)$ dan pertemuan II $(3,43)$, Observasi peserta didik pertemuan I memperoleh skor rata-rata sebesar $(3,10)$ dan pertemuan II $(3,50)$, hasil belajar diambil dari hasil tes tertulis dan kegiatan dilapangan (praktik) yang dilakukan adalah $(62,13)$ dan $(69,40)$

\section{Tahap Refleksi}

1. Renungan data hasil perolehan data pada siklus I

2. Pengolahan data hasil observasi guru, peserta didik dan tes tertulis.

3. Mencocokkan hasil yang ada dengan Indikator keberhasilan.

4. Merencanakan perbaikan terhadap jenis tindakan yang menyebabkan belum tuntas Indikator keberhasilan. Oleh karena Indikator keberhasilan belum terbukti maka penelitian dilanjutkan ke siklus II.

\section{DESKRIPSI SIKLUS II \\ Tahap Perencanaan}

Pada tahapan ini jenis kegiatan yang dilakukan masih mengacu pada kegiatan siklus I, bedanya hanya terjadi perbaikan seperlunya yaitu: 1) penyusunan RPP dengan mengacu pada pendekatan CL tipe Jigsaw dan penyempurnaan pada bagian skenario pembelajaran, 2) menyiapkan alat, sumber, bahan yang diperlukan dalam proses tindakan dikelas senyatanyan, 3) menyiapkan lembar observasi guru dan lembar observasi peserta didik sebagaimana pada siklus I, 4) menyiapkan alat evaluasi sebagaimana yang telah dibuat pada siklus I. 
Secara umum tahapan pelaksanaan proses pembelajaran pada siklus II ini masih mengacu pada pelaksanaan proses pembelajaran sebelumnya. Yang dilakukan pada proses pembelajaran ini adalah: 1) pelaksanaan proses diskusi kelompok kecil lebih dioptimalkan, 2) pelaksanaan pembimbingan kelompok sekaligus observasi peserta didik lebih di efektifkan. Utamanya pengamatan peserta didik yang aktif, yang kurang aktif, peserta didik yang tidak aktif, dengan harapan proses analisa data lebih signifikan, 3)laporan hasil kerja kelompok yang dibuat secara individu lebih difokuskan, dan 4) pelaksanaan tes tertulis sebagai tolak ukur keberhasilan peserta didik lebih dioptimalkan.

\section{Tahap Observasi}

Observasi guru pertemuan I memperoleh skor rata-rata sebesar $(4,14)$ dan pertemuan II $(4,46)$, Observasi peserta didik pertemuan I memperoleh skor rata-rata sebesar $(4,10)$ dan pertemuan II $(4,60)$, hasil belajar diambil dari hasil tes tertulis dan kegiatan dilapangan (praktik) yang dilakukan adalah $(96,33)$ dan $(89,33)$

\section{Tahap Refleksi}

1. Renungan atas perolehan data hasil observasi guru, observasi peserta didik, dan hasil tes tertulis sebagai hasil dari peningkatan aktifitas dan hasil belajar peserta didik di kelas senyatanya.

2. Pengolahan data hasil observasi guru, observasi peserta didik dan tes tertulis

3. Mencocokkan perolehan data hasil tindakan dengan Indikator keberhasilan yang telah ditetapkan.

4. Guru memberikan hadiah/reward kepada semua peserta didik kelas V.B atas keberhasilannya dalam upaya meningkatkan aktifitas dan hasil belajar dan perolehan hasil belajar sesuai dengan KKM yang telah ditetapkan.

\section{PEMBAHASAN}

\section{SIKLUS I}

\section{Tahap Perencanaan}

Pada tahapan ini kegiatan yang dilakukan adalah menyusun RPP, menyiapkan alat, sumber, bahan yang diperlukan dalam proses pembelajaran, menyusun instrument observasi guru maupun instrument observasi Peserta didik. Ada beberapa kendala yang dihadapi, tetapi setelah meminta petunjuk dan arahan kepada pembimbing kendala pun dapat diatasi dengan baik.

\section{Tahap Pelaksanaan}

a. Kelompok Kooperatif

- Peserta didik yang berjumlah 30 orang dibagi menjadi 10 (sepuluh) kelompok, masing-masing kelompok beranggotakan 3 orang

- Masing-masing anggota kelompok diberikan kartu soal yang berlainan untuk dikerjakan secara individual dalam waktu yang ditentukan.

b. Kelompok Ahli

- Peserta didik yang memiliki kartu soal yang sama dikumpulkan sehingga menjadi 3 (tiga) kelompok besar, dan masing-masing kelompok beranggotakan 10 orang (kelompok ahli)

- Ketua kelompok ahli mendiskusikan soal yang sama untuk dipecahkan secara bersama-sama

- Hasil kesepakatan semua kelompok di tulis oleh semua anggota di lembar kerja yang telah disiapkan

- Masing-masing kelompok merencanakan cara menyampaikan dengan anggota kelompok semula yang selanjutnya disebut dengan kelompok tiga serangkai

c. Kelompok Tiga Serangkai

- Masing-masing anggota kelompok secara bergiliran menyampaikan hasil kerja kelompok ahli

- Masing-masing anggota kelompok mencatat hasil dari kerja kelompok ahli.

Kegiatan pembelajaran diakhiri dengan tes tertulis dan kegiatan di lapangan (praktik), hal ini dimaksudkan untuk mengetahui peningkatan hasil belajar peserta didik kelas V.B SD Negeri 19 Cakranegara semester dua tahun pelajaran 2017/2018 dengan penerapan pendekatan cooperative learning (CL) tipe Jigsaw. Asumsi bila aktifitas dan hasil belajar meningkat maka akan terjadi peningkatan hasil belajar pula.

\section{Tahap Observasi}


Observasi guru memperoleh skor ratarata pertemuan I $(3,00)$ dan pertemuan II $(3,43)$, hasil observasi peserta didik dalam upaya peningkatan aktifitas dan hasil belajar Penjaskes peserta didik kelas V.B semester dua tahun pelajaran 2017/2018 di SD Negeri 19 Cakranegara diperoleh skor rata-rata pertemuan I $(3,10)$ dan pertemuan II $(3,50)$. Perolehan nilai rata-rata tes tertulis dan praktik dilapangan adalah $(62,13)$ dan $(69,40)$ kategori cukup.

\section{Tahap Refleksi}

Hasil analisa data perolehan aktifitas dan hasil belajar pada siklus I ini $(3,30)$ sedangkan yang diminta dalam Indikator keberhasilan $(\geq 4,0)$, ini artinya belum berhasil. Karena Indikator keberhasilan belum tercapai, penelitian tindakan kelas (PTK) dilanjutkan ke siklus II dengan harapan optimalisasi penerapan strategi pembelajaran dengan pendekatan CL tipe Jigsaw dapat meningkatkan aktifitas dan hasil belajar Penjaskes peserta didik kelas V.B semester dua tahun pelajaran 2017/2018 di SD Negeri 19 Cakranegara.

\section{SIKLUS II}

\section{Tahap Perencanaan}

Peneliti menyusun Rencana Pelaksanaan Pembelajaran (RPP) dengan memperhatikan kesalahan-kesalahan pada siklus I. peneliti lebih memfokuskan tentang Rencana strategi jitu sehingga proses pembelajaran dengan pendekatan cooperative learning (CL) tipe jigsaw dapat terelaisasi dengan baik, karenanya dalam penyusunan skenario benar-benar dirinci dari tiap aspek pada proses pembelajaran dengan jigsaw.

Sebelum proses pembelajaran dilaksanakan, peneliti menyiapkan semua alat, bahan, dan segala sesuatunya sehingga dalam pelaksanaan proses pembelajaran berjalan sesuai dengan skenario yang telah direncanakan. Agar proses pembelajaran dapat teratasi maka peneliti juga menyiapkan lembar observasi guru dan lembar observasi peserta didik sebagai tolak ukur ketercapaian peningkatan aktifitas dan hasil belajar Penjaskes peserta didik kelas V.B SD Negeri 19 Cakranegara.

\section{Tahap Pelaksanaan}

Pada tahap pelaksanaan di siklus II ini pada dasarnya masih mengacu pada pelaksanaan siklus I, yaitu penerapan pendekatan cooperative learning (CL) tipe JIGSAW. Bedanya pada siklus ini lebih dioptimalkan.

\section{Tahap Observasi}

Pada siklus II ini hasil observasi memperoleh skor rata-rata pertemuan I $(4,14)$ dan pertemuan II $(4,46)$, upaya meningkatkan aktifitas dan hasil belajar Penjaskes peserta didik kelas V.B semester dua tahun pelajaran 2017/2018 di SD Negeri 19 Cakranegara diperoleh skor rata-rata pertemuan I $(4,10)$ dan pertemuan II $(4,60)$, dampak nyata dari meningkatnya aktifitas dan hasil belajar adalah prestasi belajar juga meningkat, dari data hasil perolehan nilai rata-rata tes tertulis dan praktik dilapangan adalah $(96,33)$ dan $(89,33)$ ini berarti mengalami peningkaatan yang signifikan.

\section{Tahap Refleksi}

Hasil analisa data peningkatan aktifitas dan hasil belajar peserta didik pada siklus II adalah $(4,35)$ sedangkan Indikator keberhasilan $(\geq 4,0)$. Ini artinya pada siklus II hasilnya telah melampaui Indikator keberhasilan. Hasil belajar pada siklus I $(65,77)$ sedangkan pada siklus II $(92,83)$, ini artinya indikator keberhasilan telah dilampaui.

Karena Indikator keberhasilan telah terbukti, maka tidak perlu ada upaya perbaikan dan penyempurnaan. Pendekatan cooperative learning (CL) tipe Jigsaw telah mampu meningkatkan aktifitas dan hasil belajar peserta didik yang ditandai dengan tercapainya Indikator keberhasilan dan terjadinya peningkatan hasil belajar peserta didik. "Penelitian Tindakan Kelas (PTK) dihentikan pada siklus II dengan hasil memuaskan."

\section{SIMPULAN}

Data komulatif dari hasil penelitian tindakan kelas (PTK) dari siklus I ke Siklus II adalah sebagai berikut: 


\begin{tabular}{|c|l|c|c|c|c|c|}
\hline \multirow{2}{*}{ No } & \multirow{2}{*}{ Jenis Kegiatan } & Pertemuan & $\begin{array}{c}\text { Indikator } \\
\text { Keberhasilan }\end{array}$ & $\begin{array}{c}\text { Siklus } \\
\text { I }\end{array}$ & $\begin{array}{c}\text { Siklus } \\
\text { II }\end{array}$ & Ket \\
\hline \multirow{2}{*}{ 1. } & \multirow{2}{*}{ Hasil Observaasi Guru } & I & $\geq 4,00$ & 3,00 & 4,14 & Tuntas \\
\cline { 3 - 7 } & II & $\geq 4,00$ & 3,43 & 4,46 & Tuntas \\
\hline \multirow{2}{*}{ 2. } & \multirow{2}{*}{ Observasi Peserta didik } & I & $\geq 4,00$ & 3,10 & 4,10 & Tuntas \\
\cline { 3 - 7 } & & II & $\geq 4,00$ & 3,50 & 4,60 & Tuntas \\
\hline \multirow{2}{*}{ 3. } & Hasil Tes tertulis & & $\geq 75,00$ & 62,13 & 96,33 & Tuntas \\
\hline 4. & Hasil Praktik dilapangan & & $\geq 75,00$ & 69,40 & 89,33 & Tuntas \\
\hline
\end{tabular}

Penerapan pendekatan cooperative learning (CL) tipe Jugsaw sangat efektif dalam upaya untuk meningkatkan aktifitas dan hasil dan hasil belajar Penjaskes peserta didik kelas V.B semester dua tahun pelajaran 2017/2018 di SD Negeri 19 Cakranegara. Fakta telah menunjukkan perolehan rata-rata skor aktifitas dan hasil belajar peserta didik pada siklus I $(3,30)$, sedangkan pada siklus II $(4,35)$, hasil belajar dari 65,77 menjadi 92,83 sudah melampaui Indikator keberhasilan yang ditetapkan. Penelitian dinyatakan "berhasil" dan dihentikan pada siklus II.

SARAN

Disarankan kepada guru sejawat untuk melaksanakan Penelitian Tindakan Kelas (PTK) dalam upaya untuk meningkatkan aktifitas dan hasil dan hasil belajar peserta didik sesuai dengan mata pelajaran masingmasing.

Disarankan kepada para semua peserta didik kelas V.B SD Negeri 19 Cakranegara untuk membiasakan belajar dengan pendekatan yang kontekstual utamanya strategi yang mampu membangkitkan aktifitas dan hasil dan hasil belajar peserta didik yang dampaknya prestasi belajar dapat ditingkatkan seperti yang diharapkan.

\section{DAFTAR PUSTAKA}

Anonim, 2018, dalam https://ekokhoerul.wordpress.com/2012/0 6/27/konsep-aktivitas-belajar-siswal, diambil tanggal 16 Januari 2018, pukul 13.46 Wita.

Anonim, 2018, dalam http://ainamulyana.blogspot.co.id/2012/0 1/pengertian-hasil-belajar-dan-

faktor.html, diambil tanggal 16 Januari 2018, Pukul 14.54 Wita

Al Hakim, S dan Riyanto, M, 2002, strategi Pembelajaran Berdasarkan Deep
Dialogue/Critical Thinking (DD/CT), Malang: PPPG IPS dan PMP

Arikunto, s. 2009, Penelitian Tindakan Kelas, Jakarta : Bumi Aksara.

Harun Rasyid dan Mansur, 2008, Penilaian Hasil Belajar, Bandung : CV Wacana Prima.

Lie, A, 2002, Cooperative Learning, Jakarta: Gramedia Widiasarma Indonesia.

Lukmanul A, 2008, Perencanaan Pembelajaran, Bandung : CV Wacana Prima.

Mukhtar, 2003, Prosedur Penilaian, Jakarta : Rineka Cipta.

Nurhadi, 2003, Yasin ,B dan Sendule.A, 2003, Kontekstual dan Penerapannya dalam KBK, Malang : Unitipetas Negeri Malang.

Robert E Slavin, 2010, Cooperative Learning Teori, riset dan Praktik, Bandung : Nusa Media.

Sardiman, 2007, Indikator Dan Aktifitas dan hasil Belajar Mengajar, Jakarta : Raja Grafindo Perkasa.

Supriono, 2009, Cooperative Learning Teori dan Aplikasi PAIKEM, Yogyakarta : Pustaka Pelajar. 